\title{
Pictorial 3 : Main Boundary Fault Zone in/around Phuntsholing, South-West Bhutan
}

ブータンの一部では主境界断層（Main Boundary Fault: MBF）が活発にうごいている。ここで紹介する写真は, イン ドとの国境の町ブンツォリンから，その東方約 $6 \mathrm{~km}$ までの国境沿いでみられる MBF 帯の地形と，破砕帯の状況である.

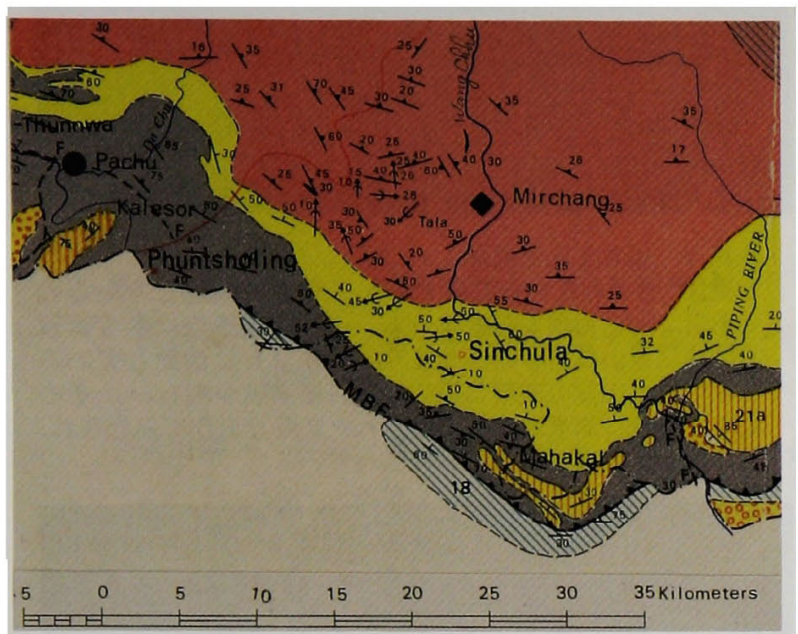

地質図 (Geological Survey of India, 1983 の一部).

最も北部のピンクの地層は片麻岩, その南の黄色は主に 珪岩からなる Thungsing 層, 灰色が Phuntsholing 層で, オレンジ縦線の石灰岩を主とする Manas 層とともにBuxa 層群に属すとされている. $\mathrm{MBF}$ と書かれた断層より南側の 空色斜線の地層はこの地質図ではシワリクとされたが, 後 に第四紀の啋層と訂正された。つまり，この地域ではシワ リク層はまだ地表に現われていないことになる.

この地質図の表題は Geological and Mineral Map of Bhutan で 1983 年刊とされており, Gansser の Geology of Bhutan Himalaya と同年であるが, インド地質調査 所では 1997 年にゲラ刷りを校正していた図書が 1995 年付 けで刊行された例もある。

写真 1 山から平野を望む1 (右).

首都のティンブーから Wang Chhu 川に沿っ て約 5 時間南下し，合板工場があるゲドの町を 過ぎて 30 分ほどの標高 $2200 \mathrm{~m}$ あたりに“ヒマ ラヤのバルコニー”と案内書で紹介される地点 がある、ここでは，まさに眼下に標高約 $200 \mathrm{~m}$ のインド平原がみえてくるが, 最近では眼下の 谷に安価な電力を利用するフェロシリコン工場 がつくられたため，煙で地形観察には適さなく なってしまった。
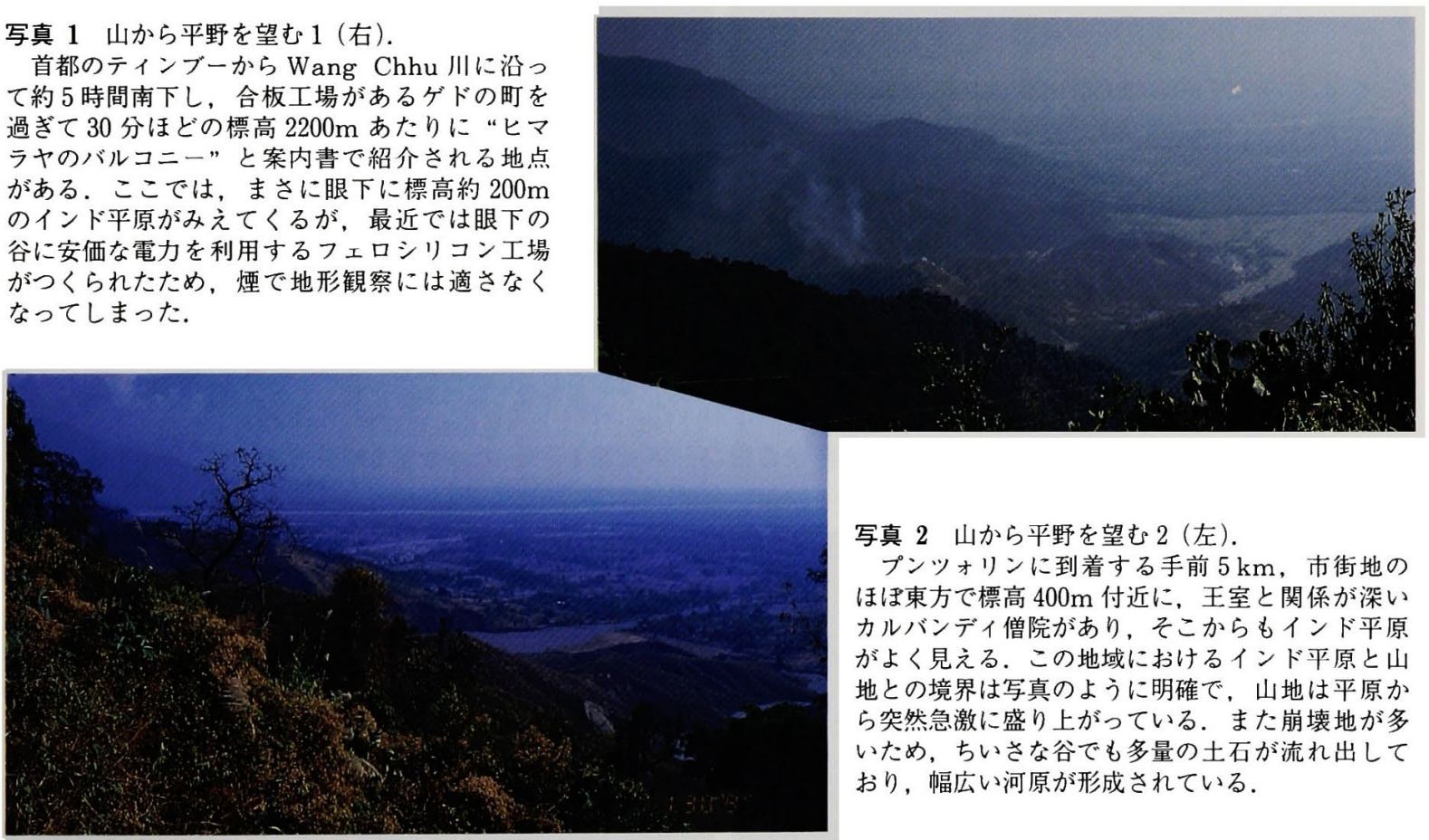

写真 2 山から平野を望む 2 (左).

プンツォリンに到着する手前 $5 \mathrm{~km}$, 市街地の ほほ東方で標高 $400 \mathrm{~m}$ 付近に，王室と関係が深い カルバンディ僧院があり, そこからもインド平原 がよく見える。この地域におけるインド平原と山 地との境界は写真のように明確で、山地は平原か ら突然急激に盛り上がっている。また崩壊地が多 いため, ちいさな谷でも多量の土石が流れ出して おり, 幅広い河原が形成されている.

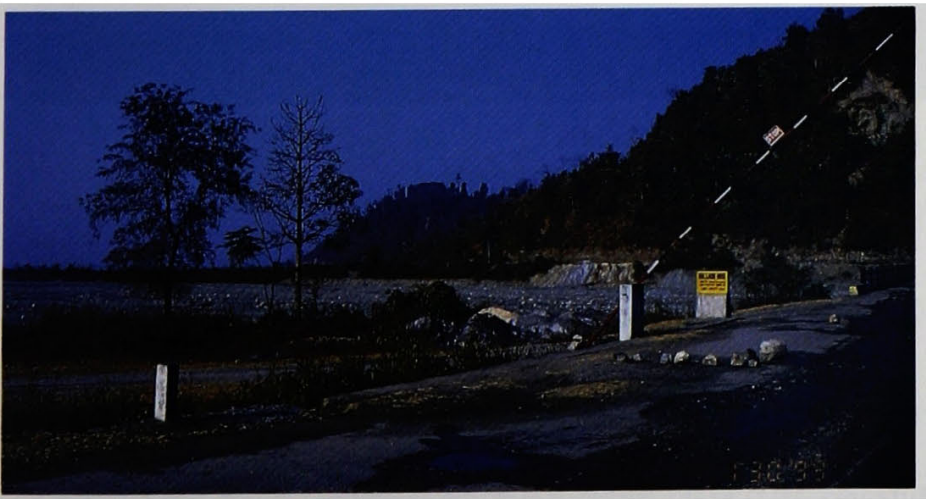

写真 3 平地と山の境界.

山はまさに突然に平地から盛り上がり，抜け出 している.ブータンは英国との戦争に敗れて山地 に押し込められ，山と平野の境界が国境とされた。 そのため, 英国の権益を引き継いだインドとブー タンとの国境線は不規則で, ブータンの国道は山 麓の国境沿いを走ることになる．写真の橋の左方 約 $200 \mathrm{~m}$ が国境であるが，ところどころに木柱が 立っているだけの国境で, 人も牛も出入り自由で ある. 河岸の露岩はすべて破砕されたプンツォリ ン層の粘板岩. 


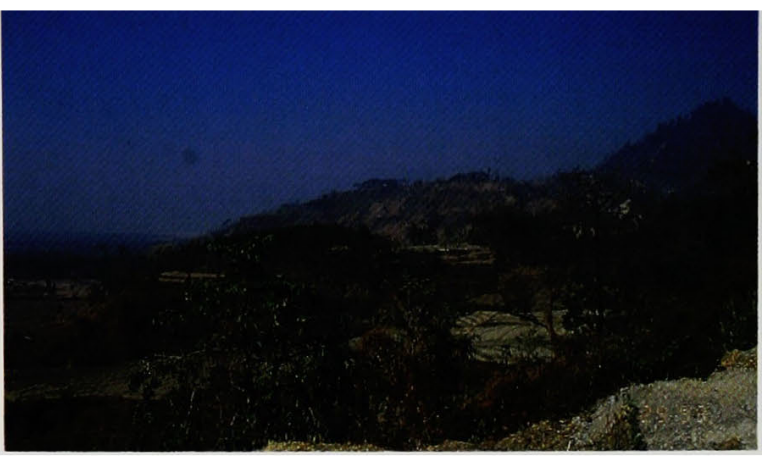

写真 4 尾根のかたち.

この地域の尾根は階段状に急勾配部と平坦部が見られる. 写真の尾根の遷緩点では激しく破砕された粘板岩が崩壊をお こしている.階段状の地形の凹部や遷緩点は MBF 带のなか でも破砕が著しいゾーンで，動きの激しい断層の位置を示し ているものと思われる.

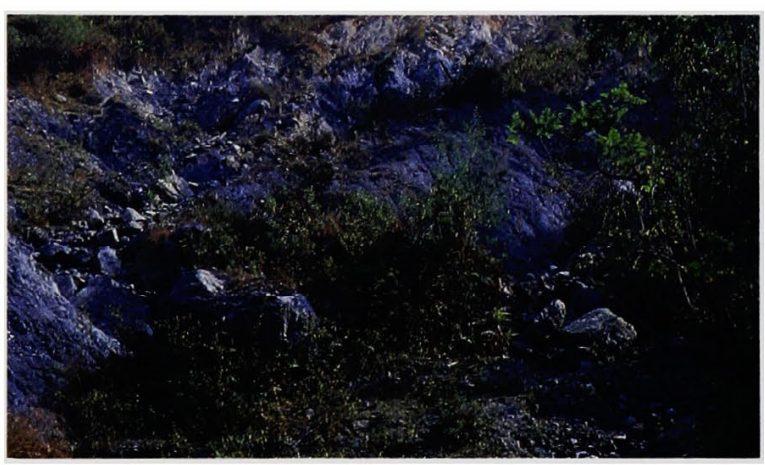

写真 6 地すべり.

雨期には斜面崩壊が多発するが, そこから供給されている 物質は， $1 \mathrm{~m}$ をこえる丸みをおびたボールダーから粘土まで， サイズは変化に富んでいる。なお，ブータンでは森林は厳重 に保護されているが,この地方に住むネパール系住民は，大 木の根元を山刀ですこしづつ削って火を付けたりして，自由 に伐採できる枯れ木をつくっている.

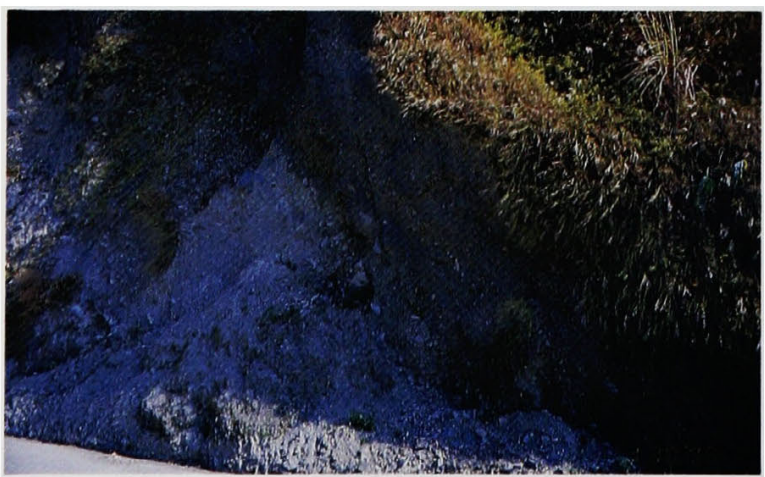

写真 8 破砕されたプンツォリン層とそれを覆うウェッジ堆 積物.

山麓沿いの道路を約 $6 \mathrm{~km}$ 走ってウェッジ堆積物が露出し ていたのは，ただ一個所であった。ここでは破砕されたプン ツォリン層の上に, やや淘汰され粘土分が洗い流されたルーズ なウェッジ堆積物が乗っているが, 古土壤は見られなかった. 粒子の配列から水の影響が推定されるので，おそらく新鮮な 斜面崩壊地に扔いて, 斜面上部の破砕帯から雨水によって洗 い流されてきた細粒部分が斜面の裾に堆積したものであろう.
写真 5 崩れる山と河原.

$\mathrm{MBF}$ 帯は幅広い破哗帯であり，急激に隆起しているの で各所で斜面崩壊が起きている。これら崩壊地は数も面積 も国境に近いほど多い。つまり，現在おもに活動している とみられる山簏の断層に近いほど斜面崩壊が激しい。 その 結果, 河原は崩壊地から供給された新鮮な岩片でみたされ, 幅の広い白っぼい河原が形成されている。

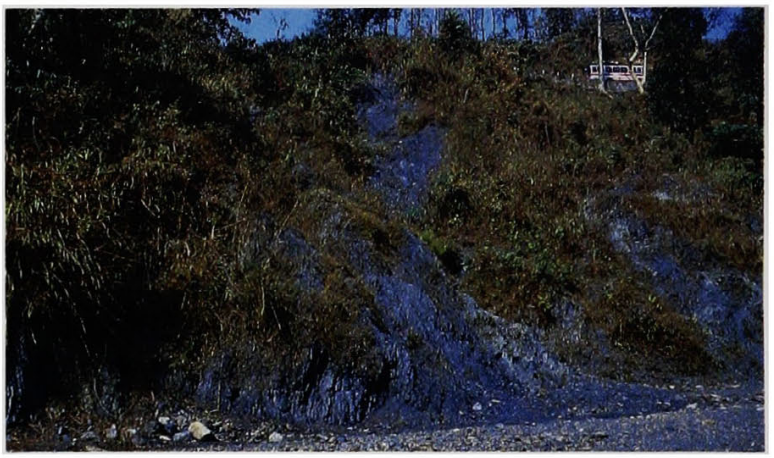

写真 7 破砕されたプンツォリン層.

プンツォリン層は Nautiyal et al. (1964) によってプン ツォリン北部の紫色千枚岩, 珪岩, 珪質石灰岩などからな るバクサ層群最下部の地層に対して命名されたが, Tangri （1995）により白色細粒の珪岩を挟む灰色や緑色の千枚岩類 と再定義された。上下は衝上断層で切られており, 化石は 産しないが時代は先カンブリア紀から三畳紀とされている.

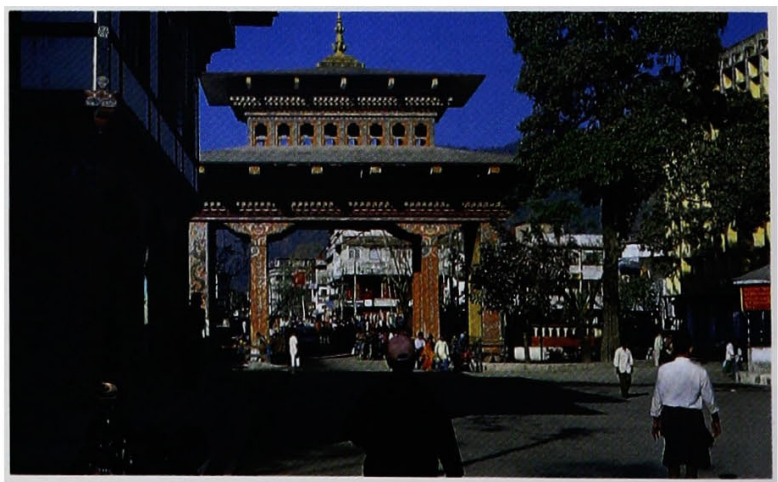

写真 9 国境のゲイト

インドからブータンへの入りロに, 有名なブータン・ゲ イトがある. インド側は混沌・雑踏の町ジャイガオンで, ブータン側がプンツォリンであるが，インドの金持ちは治 安の良いブータン側に住んでいる人が多い. 左側の建物は 警察と税関であるが，国境の出入りはほとんど自由である。

インドに住むネパール系過激派は,ブータン南部にネパー ル系の自治区を設立したいとかで，ときどきデモ隊をこの ゲートから侵入させてトラブルをおこしている。 